\title{
Democracies under stress
}

\author{
Jordi Vaquer
}

Abstract: Liberal representative democracy is going through difficult times in Europe. Democratic malfunction is present both at national level and in the European Union. The democratic deficit of the EU is connected to national failures, but also has its own dynamics. Across Europe, politicians and activists are exploring alternatives to close the gap in trust and connection with citizens, at times opening the door to further deterioration of the democratic fabric. To overcome the current national-populist challenge, meaningful democratic reform at national and EU level is indispensable.

Keywords: Liberal representative democracy, European Union, democratic deficit, national-populist challenge, democratic reform.

Author: Jordi Vaquer is Director for Global Foresight and Analysis at the Open Society Foundations, a global philanthropic organisation that works to build vibrant and inclusive democracies whose government are accountable to their citizens. Vaquer is also a contributor to Spanish media on international affairs and EU politics, and teaches at the Barcelona Institute for International Affairs.

jordi.vaquer@opensocietyfoundations.org

(C) The author(s) 2020. This is an open access article licensed under a

Creative Commons Attribution-NonCommercial-NoDerivs 4.0 Unported License 
In a remarkable departure from the triumphant post-1989 narrative, the glow of liberal representative democracy as the only successful blueprint for governance in Europe is waning. Alternative, authoritarian models of governance are increasingly contesting power, when not holding it, across the continent. The difficulties of liberal democracy are deepest and most worrying at the level for which it was designed, the nation-state. Yet, they are most challenged at the local level, where people can see them directly at play, and at the European stage, where the 'democratic deficit' discussion has been alive for decades.

Representative liberal democracy must transform in order to escape from its current predicament and continue to be a successful mode of governance in Europe. On paper, this could probably happen without the current level of European integration. However, with the present correlation of forces, a rolling back of the European Union-partial or wholesale devolution, if not dissolution-is more likely to embolden the populist, nationalist forces that are eroding liberal democracy than to open a space for separate and independent renaissances of national democracies.

Why is this so? Many reasons can explain the success of nationalism/populism, but transformations in the communications space (for example, the growth of social media), the legacy of technocratic governance and anxieties about immigration, are central. This is no coincidence. Immigration links together the four defining challenges of our time in Europe: the implosion of the social contract (that is, the shrinking of the welfare state and growing inequality); an accelerated advance towards environmental disaster; a vicious circle linking demographic decline (for example, aging populations) and cultural anxieties; and the rapid erosion of Europe's ability to shape the global environment. Without successfully addressing these four challenges and the issue that represents them most tangibly in the eyes of many Europeans - immigration -no amount of democratic renewal will bridge the gap between the rulers and the general population.

\section{DEMOCRATIC MALFUNCTION}

Parliamentary electoral politics, the characteristic form that liberal democracy takes across Europe, is in trouble. When, in 2010-11, Belgium took 541 days to form a government, all of Europe seemed slightly bemused by the extravagance of a system often depicted as dysfunctional. No country has beaten that mark since, but other national records have been broken: it took 116 days to form the current government of Germany, 131 for Sweden, 177 for the Czech Republic and 225 for the Netherlands. Italy and Greece in 2013 had to repeat elections before a government could be formed; 
Spain did the same in 2015-16 and, again, in 2019. ${ }^{1}$ The EU is by now used to dealing with interim governments that last months in power and lack a clear electoral mandate at home, but national publics are perplexed by this most basic failure of parliaments to perform their key function of providing an executive once citizens have cast their vote.

Governments composed of technocrats, votes of no confidence, snap elections, repeated elections and other exceptional mechanisms of last resort have been more frequent in the last decade than at any point since the Second World War. Even beyond providing and supporting a government, parliaments are no longer performing their fundamental political functions. To take an obvious one-representation-members of parliament look nothing like the electorate that chooses them, with a restricted number of professions (for example, civil servants, lawyers, businesspeople) vastly overrepresented. Parliaments have always been a space to stage political confrontation and accentuate differences in order to make alternatives visible. However, this used to be compensated by the ability to find some consensus and compromise on crucial issues. In times of acute polarisation, this ability is scarce, particularly when some actors inside the system have an active interest in delegitimising the functioning of parliamentary democracy per se. Finally, parliaments, and the governments they support, used to represent the absolute sovereignty of a nation's people. When their actual ability to decide is, in so many policy areas, no longer effective within national borders, that rhetorical claim to absolute sovereignty rings hollow.

National executives and parliaments are more restricted in their choices than most politicians are ready to admit in front of their national publics. The management of public affairs has become more complex and more frustrating, just at a time when successful political movements are resorting to simplification in the competition for votes. The direct de-legitimation of traditional sources of expert knowledge (the civil service, professional politicians, experienced mainstream journalists and academics), combined with resentment of the technocratic mantra 'there is no alternative', results in open hostility to the very idea of expert opinion. Information bubbles enabled by technology and the business models of global IT giants and media corporations, and the populist tactics of a number of political entrepreneurs, contribute to a world of black-and-white discussions. The gaps between what governments and parliaments can deliver, and what politicians promise and the public demands from them, and between the amount of compromise and nuance needed, and the centrifugal and accelerating pressures in the public debate, are tearing the democratic tissue apart.

\footnotetext{
${ }^{1}$ Agence France-Presse (2017).
} 


\section{IN SEARCH OF ALTERNATIVES}

The obvious failures of elective representative democracy fuel the quest for alternatives. Maintaining meaningful democratic sovereignty in the current conditions of global capitalism may be an impossible task. The first set of alternative visions, therefore, challenges the overall logic that links liberal democracy with neoliberal forms of capitalism, and proposes a radical overhaul of the economic system. However, compelling as the arguments can be, they have failed to persuade substantial parts of the electorate for a sustained period in European nations, and they are in the clear minority in the pan-European arena. In practice, the choices made in the integration process render it very hard for this alternative to grow inside the European Union in a radical manner.

While the substantive part of policies remains a contested space-one where the European Union can be an obstacle for sudden, radical change, but also an enabler for gradual, long-term transformation - reactions to the ailments of liberal democracies also focus on the practices of democracy and, in particular, citizen participation. Since the 1980s, gradual hollowing of the democratic architecture has been visible in the shape of declining turnout in elections, a fall in membership in political parties and trade unions, and less engagement in old-style mechanisms of participation, such as petitions, demonstrations and strikes. The 2008 financial crisis brought some reengagement (as a reaction to austerity), but it also compounded the situation with a drop in trust in institutions. As the crisis becomes less acute, part of the establishment may prefer a return to de-politicisation to the louder, cheaper and less predictable new forms of political activity.

The claim for direct democracy and removing intermediaries has grown stronger in the wake of the financial crisis. Technology has been central to this claim. After all, if governments can spend considerable money and effort using technologies to spy on their citizens, why could they not do the same to gauge their unmediated opinion? New political movements have created their own participatory platforms. The Five Stars movement's online platform Rousseau in Italy is perhaps the best-known example. Lack of transparency and accusations of abuse by the Five Star's leadership, as well as incidents of hacking, expose the vulnerability to control and manipulation of these instruments for participation.

The proliferation of referenda beyond the handful of countries that used them frequently in the past (Switzerland, Ireland, Italy) is another response to this thirst for direct decision. National referenda shook European integration in a more distant past (Denmark 1992, Ireland 2001, France and the Netherlands 2005) and more recently in Greece and the UK. Some proved to be useful ways of closing long political processes, but others were fertile ground for distortion, a threat to civil rights or moments of 
extreme polarisation. On the other hand, the denial of a request for a referendum (as in Catalonia) also comes with high democratic costs, once the idealisation of direct democracy has taken root in society. The spirit of referenda, with winners who only need one more vote than the losers to fully implement their agenda, is attractive to a new brand of increasingly illiberal democracies that are impatient with any kind of checks and balances on the power of the majority (interpreted as 'the will of the people'). The abuse of majorities in Warsaw and Budapest inspires nationalist authoritarians across wider Europe.

Another alternative is the idea of deliberative democracy. The essence of democracy, arguably, lies not just in decision, but also in deliberation, in considering all interests and viewpoints, and in giving decision-makers the tools to comprehend the complexity of the possible consequences of their choices. This is what elected representatives do for a job, but their subjection to the electoral cycle, the dynamics of party confrontation and the pressures of lobby groups fundamentally distort their judgement. This is why advocates of deliberative democracy believe that representative groups of people selected by lot, often called 'citizens' assemblies' or 'citizens' juries', can make fundamental contributions. Often, deliberative solutions have been adopted, piloted or suggested precisely when the traditional representative mechanisms have obviously failed. This was the case with the G-1000 experiment in Belgium (convened during the 17-month government formation crisis), Ireland's Convention on the Constitution and then Citizens' Assembly (in reaction to the shock of the crisis and bailout) and the citizens' assemblies in Gdansk, Poland (instituted after the 2016 floods). More recently, the proposal to deal with Brexit with a citizens' assembly, or France's Grand débat national (a response to the 'yellow vests' protest movement) have been likened to deliberative processes. As critics point out, deliberative democracy is by no means safe from manipulation; but it does offer an alternative road to deal with complex and highly controversial issues.

\section{THE CHALLENGE OF GOVERNING COMPLEXITY IN DEMOCRACY}

Democracies in Europe (and beyond) face three difficult sets of challenges. Firstly, they need to reverse a process of gradual disengagement of citizens punctuated by bouts of unpredictable, short-term activation. Secondly, they must operate within a global context that makes it extremely difficult to deliver on the needs and hopes of citizens, and requires a high degree of compromise in order to advance solutions. Finally, they operate in a polarised communications space, which lends itself to extreme simplification, uncompromising alternatives and easy manipulation for short-term gains. 
The governing elites could try to address the issues of disengagement and responding to globalisation with sophisticated, lengthy mechanisms of deliberative democracy, but the rowdy, fast-paced communications space makes this almost impossible. They could resort to forms of direct democracy to re-engage wider audiences by generating stark contrasts and dichotomies, but that would seldom result in the kind of nuanced, long-term solutions that will be sustainable over time. Or they could indulge in constant, endless public controversy around identity and symbolic politics while managing the substantive policies behind this smokescreen, but that would only accentuate the cynicism, mistrust and disengagement of publics in the medium term.

European liberal democracies need to find ways to regain the trust and allegiance of citizens. Contrary to the nationalist Eurosceptic mantra, this reconnection will not come from simply disentangling countries from the European Union. Neither will this reconnection materialise with the federal dream of a European-scale copy of existing national systems. Re-energising the mechanisms of elective liberal parliamentarism, and complementing them with electronic, direct and deliberative forms of participatory democracy, are all parts of the solution that national democracies need.

\section{A WAY FORWARD FOR NATIONAL DEMOCRACIES, AND FOR EUROPE}

By an almost mechanical — but fully intended - consequence of economic integration, the EU is already a transnational political arena, much more than the sum of its national democracies. In this space, the renewal of national democracies and of democracy at the European Union level can only go hand in hand. However, the bitter experience of the crisis of the common currency, for example, has proved that the European Union would not automatically work in favour of more vibrant, accountable and responsive national democracies. Indeed, the EU has its own share of problems. Transparency, ineffective accountability chains and difficulty in understanding where effective political responsibility lies are problematic. Moreover, the European Union playing field is not level: the power of some member states, and in particular some forms of corporate power, distort the decision-making processes and allow for regulatory capture. EU reform is a democratic imperative.

The politics of member states, and their transfer of problems, dilemmas and a fair amount of blame up to the European level, shape the EU. This adds to the difficulties posed by a multiplicity of governance levels, growing complexity and competing sources of legitimacy characteristic of the European level. At the same time, the scale of the problems that nation-states face, and the advanced interdependence amongst European societies, economies and polities, mean that national democracies can neither regain legitimacy and effectiveness in opposition to Europe, nor without Europe. 
In the current global environment, there simply is no meaningful democratic sovereignty to be regained by any European country by going alone. If there is any chance of citizens taking back some amount of control collectively, it is through the European Union and not outside it.

Democratic governance of the kind that many European citizens demand is not compatible with the global economic order and the role the EU plays in it. A realignment of policies and expectations is needed. Therefore, the way forward is not to defend a problematic and ineffective status quo, either in the European Union or in each individual nation, but to link the necessary reform of national democracies to that of the transnational democratic space of the European Union, and to do it both in the substance of policies and in the democratic procedures.

Liberal representative democracy has brought Europe's citizens unprecedented and unmatched levels of prosperity, rights and welfare. By pooling sovereignty and resources together in the EU, European nations have consolidated this mode of governance and helped expand it beyond the Western and Northern European core. However, the model is in trouble due to a combination of its own mistakes and limitations, and the pressure of aggressive alternative projects - in particular, the authoritarian right. Nationalists used to push to dismantle the integration project, or at least to disentangle their own country from it. Now, feeling their strength, the likes of Viktor Orbán and Matteo Salvini aspire to shape the European Union according to their worldview. Before national populism succeeds in either dismantling or capturing the EU, as well as liberal representative democracy, both the European Union and national democratic systems must react and reform. To do so simply on the defensive, trying to salvage whatever can be kept from the current system, will only delay the outcome. The politics of a way forward are the politics of courage.

\section{REFERENCE}

Agence France-Presse (2017), 'Europe's Longest Waits for a Government', European Data News Hub, 10 October. https://www.ednh.news/europes-longest-waits-for-a-government/

To cite the article: Jordi Vaquer (2020), 'Democracies under stress', Journal of the British Academy, 8(s1): 63-69. DOI https://doi.org/10.5871/jba/008s1.063

Journal of the British Academy (ISSN 2052-7217) is published by The British Academy, 10-11 Carlton House Terrace, London, SW1Y 5AH www.thebritishacademy.ac.uk 
